\title{
PROF. DR. ASLAN GÜNDÜZ'Ü ANARKEN
}

\section{Orhan OĞUZ*}

Gerçekten vatansever, heyecanlı ve bilgili bir insan olan Prof. Dr. Aslan Gündüz'ü çok erken yaşta ve ülkemizin ondan yararlanacağı günlerde kaybetmenin acı burukluğunu hissederek onun çalışmalarını yeniden hatırlamanın ve Türkiye'nin AB ile müzakere tarihi aldığı bir zamanda onu yeniden anmanın üzüntüsü içerisinde çalışmalarına yakından tanık olduğum bu değerli bilim adamını rahmetle yad ediyorum.

Türkiye'nin $\mathrm{AB}$ ile olan iliş̧ileri 45 yıllık bir geçmişe dayanıyor. $\mathrm{Bu} 45$ yılı yakından izleyen bir bilim insanı olarak bugün Prof. Dr. Aslan Gündüz'ü anarken bu karmaşık ilişsilerin gelişimini gençlerin incelemelerini ve üzerinde düşünmelerini temenni ediyorum. Esasen Marmara Üniversitesi Avrupa Topluluğu Enstitüsü de bu amaçla tarafımdan kurulmuştur. Bu Enstitünün Avrupa'daki gelişmeleri yakından takibe almasını ve $\mathrm{AB}$ ile bütünleşme de rol üstlenmesini bekliyoruz.

Türkiye - Avrupa ilişkileri zaman zaman hızlı, zaman zaman gevşek bir düzeyde sürüp gelmiştir. Önemli olan bu süreçte yetişmiş insan kapasitesine ulaşmaktır. Bunun içinde Enstitü' de yetkili, düzeyde gerçekten bu işleri en ince teferruatına kadar ulaşabilecek düzeyli bilim insanlarına ihtiyaç vardır. Bunun içindir ki Prof. Dr. Haluk Kabaalioğlu'nu genç bir hukukçu olarak İKV'de tanıdığım zaman kendisine beraber çalışma teklifinde bulunmuștum. Ondan sonra araştırma merkezindeki arkadaşlarımızın önerilerini de dikkate alarak 1987'de zamanın başbakanı Turgut Özal'a Ankara'daki bir görüşmemiz sırasında kendisinden ricam olduğunu belirttim ve Marmara Üniversitesi'ne bağlı olarak Avrupa Topluluğu Enstitüsü'nün kurulmasını istedim. O sırada yanımızda bulunan Milli

\footnotetext{
* Prof. Dr., Marmara Üniversitesi Kurucu Rektörü
} 
Eğitim bakanı Metin Emiroğlu'na Özal dönerek "bak Orhan beyin dileğini kaydet, bunu yerine getirelim" dedi. Bu tarihlerde Yükseköğretim Kanununda ki bazı değişiklikler için TBMM Milli Eğitim Komisyonu toplanıyordu. Bu önerim Milli Eğitim Bakanı tarafından Komisyona iletildi. TBMM'de adı geçen yasa değişiklikleri kabul edildikten sonra Marmara Üniversitesi'ne bağlı olarak Türkiye'de ilk defa Avrupa Topluluğu Enstitüsü kurulmuş oldu. Bundan sonra Araştırma Merkezimizin başında bulunan Prof. Dr. Haluk Kabaalioğlu'na Enstitü Müdürlüğünü teklif ettim. $\mathrm{O}$ da belli bir süre sonra bu teklifimi kabul ederek Marmara Üniversitesi Avrupa Topluluğu Araştırma Merkezinin başına geçip ciddi bir şekilde inceleme ve araştırmalarını başarılı bir şekilde sürdürdü. Yurt içinde ve yurt dışındaki değerli bilim adamlarını toplayarak Enstitünün belli bir düzeye gelmesine hizmet etti.

Prof. Dr. Haluk Kabaalioğlu'nu bu Enstitünün Müdürü olarak atadım. O da yurt içinde ve yurt dişındaki değerli bilim adamlarını toplayarak Enstitünün belli bir düzeyde oluşmasına katkıda bulundu.

$\mathrm{Bu}$ arada insan hakları, kıta sahanlığı, Kıbrıs gibi konular Avrupa Topluluğunda gündeme geliyordu. Dolayısıyla, bu konuda uzman, ahlaklı, faziletli bir bilim adamı olan doktor Aslan Gündüz'ü kurumumuza kazandırdık.

Aslan Gündüz temiz, mütevazı bir Anadolu insanı idi. Zaman zaman Enstitü'de oturup çeşitli konuları tartışırken onun vatansever düşünce ve davranışlarının öne çıktığını müşayede ederdim. Onu gerçekten çok severdim ve onun ülkemizin büyük ihtiyacı olan bu alanlarda hizmet edeceğine yürekten inanırdım. Nitekim öyle oldu, Prof. Dr. Haluk Kabaalioğlu ile güzel ve uyumlu bir işbirliği sergilediler. Ayrıca yıllarca Enstitümüzün müdürlüğünü üstlenerek de hem eğitim hayatımıza hem de Avrupa Topluluğu nezdindeki çalışmalara büyük katkılarda bulundu. Bu suretle hem Enstitümüze hem de ülkemize büyük hizmetler yaptı. Prof. Dr. Aslan Gündüz'e en ziyade ihtiyacımız bulunduğu günlerde genç yaşta aramızdan ayrılması bütün Marmara Üniversitesi ailesini yasa boğdu. Tanrıdan kendisine rahmet, değerli ailesine başsağlı̆̆ 1 ve sabırlar diliyorum. 